NBER WORKING PAPER SERIES

\title{
THE ROLE OF ECONOMIC POLICY IN SOCIAL SECURITY REFORM: PERSPECTIVES FROM THE PRESIDENT'S COMMISSION
}

\author{
John F. Cogan \\ Olivia S. Mitchell \\ Working Paper 9166 \\ http://www.nber.org/papers/w9166 \\ NATIONAL BUREAU OF ECONOMIC RESEARCH \\ 1050 Massachusetts Avenue \\ Cambridge, MA 02138 \\ September 2002
}

The authors thank Sarah Anderson, Charles Blahous, Jeffrey Brown, Rich Burkhauser, David Koitz, Kent Smetters, and Syl Schieber for comments on an earlier draft. Opinions are those of the authors and not of the institutions with whom the authors are affiliated.

(C) 2002 by John F. Cogan and Olivia S. Mitchell. All rights reserved. Short sections of text, not to exceed two paragraphs, may be quoted without explicit permission provided that full credit, including (C) notice, is given to the source. 
The Role of Economic Policy in Social Security Reform: Perspectives from

the President's Commission

John F. Cogan and Olivia S. Mitchell

NBER Working Paper No. 9166

September 2002

JEL No. H6, H3, H4, H5, I3, G2

\begin{abstract}
Recently we were asked to serve on the President's Commission to Strengthen Social Security (CSSS) along with 14 other members drawn equally from both major political parties. The Commission's charge was to provide recommendations to modernize the Social Security system, restore its fiscal soundness, and develop a workable system of Personal Retirement Accounts. This paper explains how the Commission arrived at some of its recommendations and the role that economics played in contributing to these recommendations. We describe the key institutional constraints confronting efforts to reform Social Security and how these constraints influenced Commission decisions. We also illustrate how economics research influenced the Commission's analysis of how to structure personal accounts, ways to enhance traditional Social Security program finances, and means of measuring the extent of financial progress achieved through reform.
\end{abstract}

John F. Cogan

The Hoover Institution, Stanford University

Stanford, CA 94305

cogan@hoover.stanford.edu

Olivia S. Mitchell (corresponding author)

The Wharton School, 3641 Locust Walk, Rm. 304 CPC

Philadelphia PA, 19104-6218

and NBER

mitchelo@wharton.upenn.edu 


\title{
The Role of Economic Policy in Social Security Reform: Perspectives from the President's Commission
}

\author{
John F. Cogan and Olivia S. Mitchell
}

In 2001, the two of us were asked to serve on the President's Commission to Strengthen Social Security (CSSS). ${ }^{1}$ With 14 other members drawn equally from both major political parties, our charge was to provide the President with recommendations to modernize the Social Security system, restore its fiscal soundness, and to develop a workable system of Personal Retirement Accounts (PRAs) as part of a newly structured program. ${ }^{2}$ The Commission, which included former Congressmen, former executive branch officials, and academicians, designed an economically attractive set of reforms that satisfy a wide range of objectives. In this article, we offer our impressions on how economics contributed to this endeavor. Our comments are offered to inform those interested in how economic research and analysis can shape social policy. ${ }^{3}$

In what follows, we first review the assignment we accepted when the CSSS initiated its work. Since the facts regarding Social Security's pending insolvency are relatively well known, we highlight only a few key issues. Next, we show how two ideas widely discussed by the economics profession for some time -- a pre-funded Social Security system, and personal Social Security retirement accounts -- were instrumental in shaping the Commission's thinking. Third, we briefly Congressional tendency to spend Social Security surpluses influenced our recommendations. Fourth, we discuss the proposed reforms, emphasizing where economic research played a substantive role in the design and structure of the plans. For convenience, we focus mainly on one of the Commission's reform plans: a plan that replaces Social Security's wage-indexed benefit formula with a price-indexed formula. Next, we spell out how economists contributed to thinking about transition financing, particularly regarding ways to offset traditional biases inherent in the accounting approaches taken to date. A final section concludes.

\footnotetext{
1 This article represents only our views and not necessarily the views of other Commissioners or the Administration.

2 The CSSS was co-chaired by Senator Daniel Patrick Moynihan and Richard Parsons. Besides ourselves, two other economists on the panel were Thomas Saving and Estelle James. In addition, two young economists, Jeffrey Brown and Kent Smetters, served as staff members to the Commission.

${ }^{3}$ The Commission's final report can be found at www.csss.gov.
} 


\section{The Assignment: Why Reform Social Security?}

Commissioners recognized at the outset that a common understanding of Social Security's problems would serve as an important foundation for reaching consensus on reform recommendations. Thus our work's first phase consisted of documenting the program's major problems. Since most economists are well acquainted with these problems, a brief summary of them will suffice. ${ }^{4}$

Social Security's overriding problem is a financial one. Over the next decade, benefit payments will grow faster than payroll tax revenues, and within 15 years, the program will begin to experience permanent annual cash deficits. While 15 years might seem like a long way off to the lay public, economists recognize that prudent pension policy requires taking action now. By $2037,{ }^{5}$ the Social Security Trust Fund is projected to be insolvent, meaning that the program will be legally unable to pay scheduled benefits.

Financing the deficits with higher payroll taxes will ultimately require a 50 percent increase in the payroll tax rate. The usual way of expressing the shortfall is to compute the present value of the difference between system outlays and revenues over a 75-year horizon, which is equal to 1.86 percent of payroll. This is not a small number, since it is equivalent to $\$ 3.2$ trillion in present value.

Social Security's bleak financial outlook is not its only significant problem. Because it induces workers to save less and retire early, the program's structure creates potentially substantial capital and labor market inefficiencies. ${ }^{6}$ The well-documented low returns that future retirees can expect to receive from the system represents an additional source of concern. These returns are anticipated to be around 1-2 percent for average future retirees who earn an average wage, below 3 percent for low-income retirees, and negative for some higher earners. In combination with Social Security's future funding shortfall, these low returns have eroded much of the intergenerational political support underpinning the program's success in the past.

\footnotetext{
${ }^{4}$ Readers interested in a detailed discussion of Social Security's problems are referred to the Commission's Interim Report (www.csss.gov).

${ }^{5}$ The date of insolvency for Social Security is taken from the 2001 Social Security Trustees Report. Throughout this article we refer to the economic and demographic assumptions underlying the 2001 Trustees Report, since these were used by the Commission and the Social Security's Office of the Actuary to assess financial impacts of alternative reform plans. After the Commission's Report was completed, the Social Security Trustees issued the 2002 Report, where economic and demographic assumptions changed marginally. For example, in the 2002 Trustees Report, the system's insolvency date changed by four years, to 2041 instead of 2037.

${ }^{6}$ See for instance CBO (1998).
} 
A final problem is Social Security's failure to provide adequate protection against poverty for certain groups. Commissioners, including economists, were particularly disturbed by high poverty rates among elderly women and lifetime low-wage earners. For example, one in every four divorced, separated, or never-married women over age 65 lived in poverty in 1999, the latest year for which data were available to the Commission,. Few Americans own much in the way of liquid assets: the median U.S. household owned only $\$ 17,400$ worth of financial assets, including sums in retirement accounts, in 1998. Four out of every nine households in the United States saved nothing at all in the same year, and six out of 10 African American and Hispanic households saved nothing. For these non-saving families, Social Security contributions may represent their only hope to build assets and wealth. In effect, those in the bottom half of the American population - and a larger population of the African American and Hispanic population—lack a pool of private savings to support them in old age. Meanwhile, 12.4 percent of low-income Americans' earnings are collected to support a system that offers uncertain promises and below-market rates of return. Clearly, much more remains to be done to strengthen economic security in America.

\section{Perspectives on Funding and Personal Accounts}

If a Social Security reform is to reduce the tax burden imposed on future generations, the system must move toward a prefunded program, a point made forcefully in Martin Feldstein's Presidential address before the Allied Social Sciences meeting (1996). Indeed, he and many other economists have concluded that baby-boomers' retirement would impose no additional burden on future workers, had Social Security been maintained as an investment-based retirement program with assets built up to cover future liabilities. The issue, today, however, is how to move from what is a mainly pay-as-you-go unfunded transfer program, to an investmentbased Social Security program for the future. Moving toward a funded program, the Commission agreed, would require taking one of two paths: either the federal government must invest surplus Social Security funds in capital markets, or it must permit individuals to do so in the form of personal investment accounts. 


\section{Centralized Government Investment of Social Security Surpluses}

In his charge to the Commission, the President ruled out allowing the federal government to invest Social Security surpluses in corporate securities. ${ }^{7}$ Commissioners shared the President's concern about the likely governmental response to inevitable political pressures to use the funds for political or social purposes unrelated to Social Security. Concerns expressed were of two types. First, members worried that surpluses would be used for "socially targeted" investments, rather than for diversified capital market holdings. Second, if the federal government were to become a major corporate shareholder, members worried that it would vote its shares in ways that would serve political or social objectives, at the expense of Social Security returns and the economy's overall performance. In particular, we were mindful of Alan Greenspan's argument that government investment of Social Security surpluses in stocks and bonds would have "very far-reaching potential dangers for a free American economy and a free American society". 8

Other economists reinforced these concerns with factual evidence and research results. Stanford's John Shoven offered testimony about the costly impact of the California state employee pension fund trustees' decision to divest the fund of tobacco stocks (Shoven 2001). The World Bank's Anita Schwarz testified about her analysis of government investment in other countries, where she found that most countries in which the government invested pension funds had very poor experiences. At worst, they lost money during the 1990s, and at best, they earned bank rates of return. Her pessimistic conclusion was that "experience with publicly managed funds has been disastrous" (Schwarz 2001).

Financial considerations aside, a program of government investment would also mean that government, rather than workers and retirees, would own the accumulated retirement assets. Commissioners expressed concern that without ownership of retirement assets and with no change in the program's basic benefit structure, all of the current program's adverse labor supply and saving incentives would remain in place. ${ }^{9}$

\section{Using Surplus es to Pay Down the Publicly-Held Debt}

Adopting a payroll tax-financed personal account system would mean that future Social Security surpluses would not be available for reducing the federal debt held by the public. This

\footnotetext{
${ }^{7}$ It also appeared that government investment was not a viable option within the Congress. In 1999, the Senate rejected by a 99-0 vote a proposal to allow the government to invest the Social Security surpluses in the capital market.

${ }^{8}$ Testimony before the Senate Committee on Banking, July 21, 1998.
} 
did not concern Commissioners, as we were skeptical of the federal government's ability to sustain a policy of using Social Security surpluses to pay down the federal debt. This skepticism stemmed from our reading of Social Security's legislative history and a look at federal budget policy. This history makes a compelling case against the prospect of using program surpluses to reduce publicly-held debt. From the program's inception through the mid-1990s, each time surpluses occurred as a result of policy design, a wartime economy, or a peacetime period of non-inflationary economic growth, the Congressional response was to raise benefits or liberalize eligibility. ${ }^{10}$ The process began with the original Social Security Act of 1935. The Act contained a financing plan to amass substantial surpluses during the program's early years, which were to be used to reduce federal debt held by the public. Debt reduction and the interest savings therefrom were to be credited to the Social Security program through a reserve account. Later, when Social Security was forecasted to incur deficits, the reserve account would be drawn down to finance benefit payments. ${ }^{11}$

The plan hit difficulties almost immediately. By the end of the 1930's, the Social Security system's reserve policy collapsed under pressure from those who sought to liberalize benefits, and also from fiscal conservatives who feared that surpluses might lead to higher federal spending. In 1939, Congress dissipated the surplus by raising benefits, issuing the first benefit checks a year earlier than originally planned, and granting eligibility to survivors and spouses. During the 1940s, the wartime economy again produced large Social Security surpluses. By 1950, the accumulated surpluses were sufficient to finance the next ten years of benefit payments. Again, pressure mounted to spend the surplus and Congress willingly responded. In each election year during the 1950s, Congress raised benefits or expanded eligibility. By the end of the decade, the surplus had been spent. In the 1960s, strong economic growth produced Social Security surpluses. For a third time, federal government's response was the same. Congress again boosted benefits, for a total of seven times over the nine-year period 1965-73. These

\footnotetext{
${ }^{9}$ This point was made by Shoven in his testimony before the Commission (2001).

${ }^{10}$ For background on this discussion see Weaver (1982), Cogan (1998), and Schieber and Shoven (2000).

${ }^{11}$ President Roosevelt's Treasury Secretary, Henry Morgenthau articulated this policy in testimony before the House Ways and Means Committee in 1935: "The reserve would be used to progressively replace the outstanding public debt with the new liability...for old-age annuities. To the extent that the receipts from the old-age annuity taxes are used to buy out present and future holders of Government obligations, that part of the tax revenues that is now paid out to private bond holders will be available for old-age annuity benefits" (Committee on Ways and Means (1935, page 899 ). In 1939, the reserve fund was replaced by the Social Security Trust Fund.
} 
benefit increases totaled 83 percent, and along with a poorly-performing economy, they brought Social Security to the brink of insolvency by the mid-1970s.

Since then, Congress has not significantly raised Social Security benefits. However, the failure to do so does not mean that politicians recognize the importance of using program surpluses to prepare for the baby-boom's impact. Deficits plagued the program until the mid1980s. The surpluses during the next ten years were modest in size. In fact, it was not until 1992 that the surpluses accumulated to one year's worth of benefit payments. And, two years later, facing deficits in the disability program that threatened payments to currently disabled workers, Congress enacted legislation to divert funds from Social Security old-age program to the disability program. ${ }^{12}$ This tax diversion, which continues today, will total about $\$ 160$ billion by the end of this fiscal year.

Commissioners also felt that there was little reason to believe that Social Security surpluses remaining after the legislative actions just described had been used to reduce the debt. In our view, it was more credible that Social Security surpluses have produced an increase in federal spending on non-Social Security programs and tax reductions. There is little hard research evidence on Social Security's impact on the rest of the budget, ${ }^{13}$ but our view has been supported by a broad spectrum of economists. For instance, at a 1989 American Enterprise Institute Conference on Social Security, conference participants Alan Blinder, Barry Bosworth, James Buchanan, William Nordhaus, James Poterba, John Shoven, and Carolyn Weaver all expressed the view that previous Congresses had spent Social Security surpluses (Weaver 1990). Similar conclusions were reached by Aaron, Bosworth, and Burtless (1988) and earlier by Munnell and Blais (1984).

This review suggested to Commissioners that, in view of past Congress' persistent tendency to spend Social Security surpluses, it would be imprudent to assume that future Congresses would behave differently. This conclusion was reinforced by budgetary events that occurred during the Commission's deliberations. The economic recession, appropriations increases, and a tax cut transformed the projected unified budget surpluses into budget deficits.

\footnotetext{
${ }^{12}$ Formally, this was accomplished by raising the Old-Age and Survivors Insurance tax rate and reducing the Disability Insurance tax rate by equal amounts.

${ }^{13}$ The only systematic economic analysis of the issue, by Crain and Marlow (1990), found statistical support for the conclusion that Social Security surpluses led to more non-Social Security spending.
} 
The conclusion had an important impact on several aspects of the Commission's work. First, many members felt that individually owned personal accounts would more strongly insulate workers' Social Security taxes from political pressures and thereby improve the chances of pre-funding. While it is unlikely that future Congresses could be completely precluded from using workers' accounts for purposes other than retirement, individual ownership would make it more difficult to do.

Second, this conclusion led the Commission to focus on the program's future cash flow shortfalls rather than on Trust Fund accounting when describing Social Security's financial problems. In our view, the Trust Fund concept serves as a useful economic and budgetary device only when surplus Social Security funds are used to reduce publicly-held debt. ${ }^{14}$ If these surpluses are used to reduce debt, the Trust Fund balance represents an economic asset, the value of which equals the amount of debt reduction and associated interest savings. On the other hand, if surpluses are used to finance more non-Social Security spending or tax reductions, then the Trust Fund balance does not represent an economic asset. Instead, it is merely a political claim on future general fund revenues.

Focusing on Social Security cash flows, by contrast, recognizes that as a practical matter of government finance, Congress will be required to take some budgetary action when the Social Security system begins to incur deficits. It will either have to raise additional revenues by taxing or borrowing, cut Social Security benefits, or free up revenue by cutting other government programs. Cash flow accounting is useful because it shows clearly the timing and amount of expected action the government will have to take.

Another consideration is that trust fund accounting can give a misleading assessment of any reform's long-term impact on federal finances. When Social Security surpluses are not used to reduce the federal debt and, instead, are spent on current consumption, the accounting system improperly credits trust fund with a financial asset. In this accounting system, the cost of policies such as personal accounts is overstated. The accounting system's cost includes both the value of this financial asset and the foregone returns on it. The true economic cost, however, is only the foregone present consumption.

The Trust Fund's use of a 75-year time horizon can also produce a misleading assessment of personal account's impact, even if future trust fund surpluses were used for debt reduction.

\footnotetext{
${ }^{14}$ In practice, the accounting system credits the trust fund regardless of how the surplus funds are used.
} 
Payroll-tax financed personal accounts reduce the trust fund's net income during the early years of the policy. In later years, as personal account annuities replace Social Security liabilities, the trust fund's net income rises. A fixed time horizon truncates the years of net income gain, and thereby, produces downwardly biased estimates of the Social Security Trust Fund's improvement from personal accounts.

The magnitude of the bias is not trivial. Consider a plan under which workers could divert two percentage points of the payroll tax rate into personal accounts. Assume that those who opt for personal accounts are required to forgo in traditional Social Security benefits the diverted contributions plus a three percent real rate of return on these contributions. Since, under the Trustees' assumptions, the three percent real return is precisely what the trust fund would have earned on these funds, the policy is financially neutral for the trust fund in perpetuity. However, if the 75-year horizon is used to assess the policy, the long-run actuarial imbalance is increased from its current level of minus 1.86 percent of payroll, to minus 2.46 percent, a 32 percent increase.

This problem can be easily avoided by simply extending the accounting time horizon in perpetuity. Alternatively, many economists have proposed to use generational accounting to track Social Security and other long-term fiscal liabilities not currently tracked on budget. ${ }^{15}$ Adopting this longer-term perspective would remove the budget's current bias against prefunding implicit long-term liabilities and give policymakers the necessary tool for making and justifying more informed long-term decisions

\section{How The Commission's Proposals Evolved}

Commissioners never seriously considered "privatizing” all of Social Security by allowing workers to invest their entire payroll taxes in private securities, believing that the idea was too radical a departure from the current program. Furthermore, full privatization was inconsistent with the President's public statements. He had proposed that personal accounts

\footnotetext{
15 The generational accounting approach was developed by Alan Auerbach, Jagadeesh Gokhale and Lawrence Kotlikoff (1991).
} 
augment the current program by giving individuals another option within the Social Security system. $^{16}$

\section{A Two-Tiered System}

Commissioners concurred that any Social Security reform plan we proposed would have two interrelated components or tiers. A traditional Social Security program, Tier I, would continue to serve a key safety net role, intended to alleviate the problem of poverty in old age. Its benefit structure would be modified in several ways (discussed below) to improve its role as a backstop against poverty. The Personal Retirement Accounts (PRAs), Tier II, would serve as an investment-based component that would enhance individuals' ability to build financial wealth as a source of retirement income.

For practical reasons, the Commission also thought it sensible to build on existing approaches rather than to propose new and untested plans. The idea of a two-tiered program has been the subject of considerable past academic work, is regarded as a mainstream idea in Washington's policy circles, and has been implemented in several countries. The essential elements of a two-tiered United States program were presented to the Greenspan Commission two decades ago by Boskin, Kotlikoff, and Shoven (Boskin,1982). Since then, numerous proposals embodying a two-tier structure have been developed by reputable economists and policymakers. ${ }^{17}$ Elected officials are also familiar with the real-world example of the Federal Thrift Saving Plan, which is the retirement program for civil servants adopted some 15 years ago. Furthermore, many Congressmen and Senators have proposed similar approaches, and all key Social Security reform plans introduced in the $104^{\text {th }}$ Congress included a two-tiered structure. Finally, a two-tiered approach has been successfully implemented in a number of countries including England, Australia, and most recently, Sweden.

By means of hearings and briefings, we came to appreciate two additional policy motivations for a two-tiered structure. First, a two-tiered approach gives the Social Security program a greater degree of transparency. Since its inception, Social Security has struggled with the inherently contradictory goals of social adequacy and individual equity. The adequacy objective seeks to ensure that retirees attain a certain socially-determined standard of living in

\footnotetext{
${ }^{16}$ For example, in a speech at Rancho Coucamonga on May 15, 2000, the President opined that: "Personal accounts are not a substitute for social security. They involve only a limited percentage of the payroll tax so that the safety net remains strong... we can and must give younger workers the option of new opportunities".
} 
old age. This objective requires income transfers from high-earner to low-earner workers over their lifetimes. Individual equity, on the other hand, seeks to ensure that a worker's contributions are directly linked to his retirement benefits.

The current program's complexity is the result of years of legislative efforts to meet these competing goals with a single benefit formula. This complexity has produced a surprising number of inequities and anomalous redistribution patterns, yielding a surprisingly low level of redistribution. ${ }^{18}$ For this reason Commissioners concluded that creating two separate tiers under Social Security, each with its own goal, could improve the overall program's transparency and equity. Thus in each of the Commission's plans, social adequacy became the principal objective of Tier I, while individual equity became the main objective of Tier II. This structure's greater transparency will enable policymakers to make more informed choices about appropriate benefit and tax levels, and it should also enable plan participants to make better savings and retirement decisions.

Another policy rationale for a two-tiered system is that it would likely entail less risk than a single-tiered program. ${ }^{19}$ Contrary to conventional thinking, current Social Security promises involve substantial political and economic risk. ${ }^{20}$ The political risk is that Congress will alter future benefits, a natural concern given the program's legislative history. Congress has reduced the growth in Social Security benefits in each of the last three decades, ${ }^{21}$ and in some instances

\footnotetext{
${ }^{17}$ See Weaver (1990), Gramlich (1996), Feldstein and Samwick (1998), Schieber and Shoven (1999), Moynihan (1998), and Koitz (2001), among others.

18 The Commission specifically focused on work by Gustman and Steinmeier (2000), Coronado, Fullerton and Glass (2000), and Liebman (2001) in this regard.

${ }_{19}$ The September 6 testimony of John Shoven was particularly influential on this point.

${ }^{20}$ Despite considerable confusion on this point among public policy officials, the news media, and the public at large, traditional Social Security benefits are not "guaranteed". As the Social Security Administration has explained:

"There has been a temptation throughout the program's history for some people to suppose that their FICA payroll taxes entitle them to a benefit in a legal, contractual sense. That is to say, if a person makes FICA contributions over a number of years, Congress cannot, according to this reasoning, change the rules in such a way that deprives a contributor of a promised future benefit.... Congress clearly had no such limitation in mind when crafting the law...Like all federal entitlement programs, Congress can change the rules regarding eligibility--and it has done so many times over the years. The rules can be made more generous, or they can be made more restrictive. Benefits which are granted at one time can be withdrawn, as for example with student benefits, which were substantially scaled-back in the 1983 Amendments." ( Social Security Administration website; http://www.ssa.gov/history/nestor.html)

Further, the Supreme Court has ruled in Flemming vs. Nestor (1960) that workers and beneficiaries have no legal ownership over their benefits, even after a lifetime of paying taxes into the system. All this makes the Social Security system very uncertain, contingent on the hope that politicians elected 20-30 years from now be able to generate the revenue needed to pay scheduled benefits.

${ }^{21}$ Legislation reducing scheduled benefits was passed in 1977, 1983, and 1993.
} 
benefit changes have been rather substantial. For example, the 1977 Amendments reduced benefits by 19 percent from their promised levels for workers who were age 62 in 1980, and 30 percent for workers age 54 in $1980 .{ }^{22}$ Going forward, the political risk of achieving a given level of retirement income is arguably much larger, since the system faces even more widespread shortfalls as a result of its insufficient financing. There is also economic risk stemming from the linkage between benefit promises and national average earnings: given an individual worker's lifetime wage profile, also produces variations in Social Security benefits. ${ }^{23}$ Social Security's benefit formula, in effect, spreads "productivity" risk among both workers and retirees, at least up to the age of retirement. Both factors impart additional risk in benefits promised under the current system.

Achieving a given level of retirement income through investment-based individual accounts is, of course, also subject to uncertainty due to capital market volatility. This risk differs from the risks associated with traditional Social Security benefits. Elementary portfolio theory states that the overall level of investment risk can be reduced through diversification. A twotiered Social Security program allows workers to diversify their investments and, thereby, lower the overall risk of achieving a given level of retirement income.

\section{Changes in First Tier Benefits}

Drawing on prior research, Commission members knew that personal accounts alone would not put the Social Security program on a sound financial basis. To meet the President's charge to restore the program's fiscal soundness without raising taxes permanently would therefore require additional steps to reduce future liabilities. In assessing its options, the Commission undertook a review of the current policy for determining benefits, its history, and its implications for future costs. ${ }^{24}$ In particular, our research investigated current benefit promises and the role of wage versus price indexing in the benefit formula.

\footnotetext{
22 The Commission on the Social Security Notch Issue, Final Report, Washington, D.C., 1994, page 78.

${ }^{23}$ An underappreciated point is that the Social Security program's benefit formula could subject low-wage workers to greater economic risk than high-wage workers. This is because for a low-wage worker, an additional dollar of lifetime annual earnings adds 90 cents to Social Security benefits, while for a high-wage worker, each additional dollar adds only 15 cents to benefits. For this reason, fluctuations in lifetime pay and/or the national average wage could produce larger variations at the lower end of the pay distribution. Empirical research to evaluate this hypothesis would be useful.

${ }^{24}$ This review was conducted by a sub-group of Commissioners known as the "Fiscal Subgroup", headed by cochairman Richard Parsons. It included the Commission's four economists as well as Lea Abdnor, Gerald Parsky, Tim Penny, and Robert Pozen.
} 


\section{Current Benefits Policy and Its Legislative History}

Under current law, there are two steps to calculating initial Social Security benefits. The first is to compute a worker's average monthly earnings over his or her working career. The second is to compute monthly benefits based on the worker's average monthly earnings. Presently, both computations are tied to the growth in the national average taxable earnings, so Social Security's initial benefits are said to be "wage-indexed". ${ }^{25}$ The main rationale for wageindexing is that it tries to ensure that initial benefits for each cohort of retirees replace a specified portion of the typical retiree's pre-retirement earnings. Under current rules, a worker who earns median wages over his entire career receives an initial benefit worth roughly 40 percent of the median wage when he retires.

Wage-indexing has been part of the Social Security program for less than half its history, in fact for only 23 years in the last 67. From the program's inception in 1935 until 1975, indexing of any form was not used for benefit calculations. That is, neither workers' wage histories nor benefits for currently retired workers were indexed to wage growth or inflation rates. Instead, benefit increments were enacted on an ad hoc basis. When deciding whether to grant a benefit increase, each Congress balanced the social adequacy of benefit levels against the availability of resources to finance the increase. When assessing social adequacy, Congress focused mainly on preserving the purchasing power of benefits, while paying little attention to wage replacement rates (Hsiao, 1979). ${ }^{26}$

Indexing initial benefits began in 1975 in response to double-digit inflation rates that eroded the purchasing power of benefits for retirees. Four years later, in 1979, the current wageindexing policy was instituted to correct a flaw that had "over-indexed" benefits and led to imminent insolvency. During these years, two congressional advisory committees offered conflicting recommendations regarding the calculation of initial benefits. The 1974 Social Security Advisory Council recommended wage-indexing. The 1975 Consultant Panel on Social

\footnotetext{
${ }^{25}$ Specifically, to compute a worker's average indexed monthly earnings (AIME), the workers highest 35 years of earnings are indexed to the average growth in earnings covered by Social Security. In 2001, a single worker who retires at the normal retirement age receives in benefits 90 percent of the first $\$ 561$ of monthly AIME; 32 percent of each additional dollar of AIME up to $\$ 3,381$, and 15 percent of each additional dollar of AIME thereafter. These dollar amounts that define the ranges over which percentage replacement rates are applied, called bend points, are indexed to the growth in average earnings of all workers covered by Social Security.

${ }^{26}$ The 40 percent replacement rate policy established in the 1977 law was significantly higher than the replacement rates received by workers who had retired prior to the early 1970s. As late as 1970, the replacement rate for a worker with median wages was only 34 percent. (Committee on Ways and Means 2000).
} 
Security rejected this approach in favor of one that price-indexed earnings histories. ${ }^{27}$ Congress ignored the Consultant Panel's warnings that financing a wage-indexed system would ultimately require a 50-80 percent increase in the payroll tax rate, ${ }^{28}$ when it implemented wage-indexing. Implications of Wage-Indexing.

Under a wage-indexed system, initial benefits rise from one retirement cohort to the next, at the rate of growth in average earnings of all workers covered by Social Security. Owing to increases in worker productivity, wages generally grow faster than prices, so the purchasing power of Social Security benefits under such a system rises from one retirement cohort to the next. The Social Security Trustees' intermediate assumptions for 2001 project that real wages will grow at a 1.3 percent average annual rate during next 10 years, and at a 1 percent annual rate thereafter. $^{29}$

A 1 percent annual real wage growth rate in excess of prices translates into a sizeable increase in the purchasing power of benefits over time, with concomitant increases in costs to pay for them. Figure 1 indicates the projected retirement benefit increases scheduled under current rules, for "typical" workers of various ages. Typical workers are defined as those who, in each year of labor force participation, earn the average Social Security taxable wage. As the results show, the typical worker age 45 in 2001 who retires at age 65 is scheduled to receive a monthly payment that is 20 percent higher in real terms than the benefit paid to the typical worker retiring in 2001. Similarly, scheduled benefits for today's teenagers are scheduled to be 60 percent higher than benefits paid to a typical worker who retired in $2001 .{ }^{30}$

Figure 1 here

This growth in inflation-adjusted scheduled benefits for future retirees represents a significant part of Social Security's expected future cost increase, one that requires a 50 percent payroll tax rate increase to finance it on a pay-as-you-go basis. Putting it differently, actuarial calculations performed for the Commission show that the entire increase in Social Security's cost rate going forward in time can be accounted for by the increase in inflation-adjusted benefits. Conversely, if the real purchasing power of benefits paid to future cohorts of retirees

\footnotetext{
${ }^{27}$ That Panel was chaired by economist William Hsiao and members included James Hickman, Ernest Moorhead, and economist Peter Diamond.

${ }^{28}$ Consultant Panel Report, page 6.

${ }^{29}$ Board of Trustees (2001), page 84 .
} 
were maintained at the level provided to today's retirees, future benefits could be paid without any increase in the payroll tax rate.

In view of these projections, the Commission concluded that continuing to wage-index Social Security would be inequitable and too costly. Wage indexing was seen as inequitable because it imposes a higher tax burden on future generations in order to provide future retirees with richer benefits (measured by purchasing power) than the benefits society is willing to pay to today's retirees. ${ }^{31}$ The policy's high cost has been repeatedly documented in Social Security Board of Trustees Reports. These reports have shown that, given the baby-boom's retirement, wage-indexing has never been consistent with system fiscal solvency. Since wage-indexing was adopted, the Trustees have found the program financially insolvent in 23 of the last 25 annual reports. Each report has contained the same alarming message: in order to finance the costs of a wage-indexed system, payroll tax rates will have to be raised by at least 50 percent. The most recent Trustees Report, issued after the Commission completed its work, reached the same conclusion.

While a wage replacement policy might have been a worthy Social Security program goal at an earlier historical period, our own view is that this goal's importance has diminished as per capita incomes have risen and other retirement savings vehicles, such as IRAs and 401k plans, have become more widely available. Wage replacement therefore can now be viewed as a desirable goal of a comprehensive pension policy, rather than as the principal and overriding objective of the entire Social Security program. This is especially true since, as we show below, a price-indexed initial Social Security benefit coupled with a personal account program can be anticipated to produce combined benefits that approximate the current program's replacement rates for lower and middle income workers.

Commissioners also voiced other objections to wage-indexing, similar to those expressed in two previous commission reports over two decades ago, namely the 1975 Consultant Panel on Social Security's report, and minority views in the 1979 Social Security Advisory Council'

\footnotetext{
${ }^{30}$ Note that these calculations include the fact that Social Security's normal retirement age is scheduled to rise to age 67 in 23 years. In the above examples, both typical workers will pay an early retirement penalty of about 7 percent for retiring at age 65 .

${ }^{31}$ It is interesting that price indexing protects real retiree income better than wage indexing, since under wage indexing, benefits are subject to productivity risk. While this may be efficient in terms of intergenerational risk sharing, it results in less old-age economic security.
} 
report. $^{32}$ One was that current practice creates an element of inequity across workers who retire within a few years of one another. With wage indexing, two workers whose retirement ages are five years apart and who have contributed identical amounts to Social Security receive different inflation-adjusted monthly benefits. This outcome obtains as long as economy-wide wages rise. Another concern is that a wage-indexed system leaves future Congresses with little financial flexibility to adjust benefits to meet future needs. Just as economic, social, and demographic change will have unknown timing and financial impacts on Social Security, so too will there be new demands on future government to provide national security, ensure health care, and combat poverty. Future Congresses will be better situated to allocate future resources among these competing claims, and Social Security policy should allow Congress that flexibility.

\section{Why Is Price-Indexing Appealing?}

"Model 2" in the Commission Report would replace wage-indexing with a policy under which initial benefits would grow from one retirement cohort to the next at the rate of growth in prices rather than wages. ${ }^{33}$ Under such a price-indexing policy, workers in successive retirement cohorts with identical real wages would automatically receive the same real monthly benefits. ${ }^{34}$ Inflation-adjusted benefits over a retiree's lifetime would continue to rise with life expectancy.

The change to price-indexing initial benefits alone would produce long-term savings sufficient to put Social Security back on sound actuarial footing. As noted earlier, the Social Security system now confronts a long-run actuarial deficit of 1.86 percent of payroll. Changing to price-indexing would reduce Social Security's long-term liabilities by 2.07 percent of payroll and thereby create an actuarial surplus of 0.2 percent of payroll over the 75 -year evaluation period. Consequently, this policy's main attraction is that actuarial solvency can be achieved

\footnotetext{
${ }^{32}$ See 1979 Advisory Council, pages 233-34.

${ }^{33}$ The Final Report issued by the Commission sketches three reform plans; for the present discussion we focus on Model 2 to illustrate key points. Readers interested in further discussion of the Commission's other two models are referred to www.csss.gov

${ }^{34}$ In practice, this policy would be accomplished by multiplying the current benefit formula's replacement rate factors by the ratio Consumer Price Index increase to the Average Wage Index increase from one year to the next. Price-indexing is not new: . in their minority views prepared for the 1979 Social Security Advisory Council, Henry Aaron and Gardner Ackley wrote: "...we recommend the enactment now of an alternative adjustment mechanism ...that would automatically assure successive generations of retirees who have the same real earnings history the same real benefit. Thus, retirees with average earnings of $\$ 1,000$ a month in all years after 1995 would receive a benefit of $\$ 469$ (in 1980 dollars). Enactment of this proposal leave to successive Congresses the opportunity to decide whether workers with a given real earnings history should receive increased real benefits, and to impose the taxes necessary to pay for them."(1979 Advisory Council, page 233-234). We also note that this policy differs from one in which wage histories and bend points are indexed to the growth in prices. This last idea was proposed by the
} 
without raising taxes permanently, while inflation-adjusted benefits for future retirees would be maintained at the level of those received by current retirees. ${ }^{35}$

An additional and very crucial appeal of this approach is that the 0.2 percent of payroll surplus can then be used to enhance the progressivity of Social Security's benefit schedule. Specifically, we proposed that the surplus, the present value of which amounts to about $\$ 300$ billion, could be allocated to raising inflation-adjusted benefits to low-wage workers and widows of deceased low-wage workers. The enhanced progressivity was a strong point to all Commission members. An additional reason to favor price-indexing initial benefits is that this change would become effective beginning in 2009, and hence it would affect only benefits paid to future retirees. No one currently over the age of 55 would have his or her benefits changed. For people currently younger than age 55, initial benefits would gradually grow one percent per year more slowly than under current law. Thus the system would be brought into balance without any abrupt changes in benefits.

Some might argue that price indexing would be difficult to implement from a political economy perspective, since politicians might be unwilling to cut future replacement rates. It is important to keep in mind, however, that Congress has reduced replacement rates on several occasions in the past. The 1977 Social Security Amendments reduced replacement rates by 30 percent for workers age 54 and younger in 1980. The 1983 amendments, by raising the "normal" retirement age and not the "early" retirement age, will reduce the replacement rate by 14 percent when it is fully phased-in. The 1993 amendments, by taxing Social Security benefits, reduced replacement rates by 7 percent for some middle income retirees and by as much as 20 percent for high income retirees. We also note that under the Commission's plans, retirement income from both tiers of the new Social Security program would generate replacement rates for low and middle-income workers that are at least as high as at present. Finally, Commissioners felt that the surplus generated by price indexing can provide future Congresses a degree of freedom with which to boost benefits, if this were deemed desirable at a future date.

1975 Consultant Panel on Social Security; under such a policy, inflation-adjusted initial benefits would grow, but at rate slower than the growth in wages.

${ }^{35}$ Since the policy would not become effective until 2009, inflation-adjusted benefits received by future retirees are expected to be slightly higher than those received by workers who retired in 2001 . 


\section{Structuring Personal Retirement Accounts (PRAs) as a New Second Tier}

All of the Commission's reform plans included a proposal to offer workers a choice to invest part of their payroll taxes in a voluntary personal retirement account (PRAs), as part of a reform that improved the Social Security system's long term fiscal status. As economists, we found this to be an interesting and challenging task for several reasons. First, our charge required that these accounts be voluntary, so they would have to be structured so participants would find them potentially attractive. A key aspect therefore was to design the plans to offer participants some investment choice, to be managed efficiently, and to be relatively inexpensive to operate. Second, the President had ruled out increases in payroll taxes, nor could general revenue be diverted to support the accounts in perpetuity. Consequently, these accounts would have to be at least partially financed by permitting workers to redirect a portion of their payroll taxes into these accounts. ${ }^{36}$ Third, these accounts would have to be designed in a way that the overall reform contributed to reducing long-term Social Security liabilities. In practice, this would require that participants who elected to contribute less payroll tax to the traditional system would also have to receive lower Tier I Social Security benefits, though of course they would receive their Tier II PRA benefits as well. Fourth, keeping fees low suggested that the accounts be made as large as possible as soon as possible, and investment choices would be limited so as to hold down management fees. Fifth, Commissioners felt that PRAs could best be targeted at lower-paid workers, since this segment of the labor force is least well-served by corporate pensions and tends to have the lowest saving rates. In addition, Social Security has traditionally had a redistributive benefit formula, paying higher proportional benefits to low-wage workers than to higher-wage employees. Consequently, we believed that targeting PRAs on lowerearners was integral to an approach that would maintain system progressivity.

\section{Designing Personal Accounts}

In order to illustrate how the policy objectives were weighed in practice, it is useful to focus again on the Commission's Model 2. Under this plan, all workers younger than 55 would be permitted to voluntarily redirect 4 percentage points of their payroll taxes, up to $\$ 1,000$, into their personal accounts. (the $\$ 1,000$ cap would be indexed to the growth in the national average wage and hence rise over time.) The personal account would enable a young worker earning

\footnotetext{
${ }^{36}$ Two of the models in the CSSS Report countenanced the possibility of having workers add on additional contributions if they opted into the voluntary accounts.
} 
$\$ 25,000$ annually to anticipate building an account worth over $\$ 150,000$ in retirement wealth (in \$2001). While all persons currently under age 55 could participate in and benefit from personal accounts, we anticipated that lower-wage workers would benefit the most since they are least likely to have company-sponsored pensions at present.

In designing the PRAs, Commissioners wanted to ensure that personal accounts would reduce Social Security's long-term liabilities. ${ }^{37}$ In practice, this can be achieved by requiring workers who opt for a personal account to forego a portion of their traditional Social Security benefit. The Commission recommended that the amount forgone depend on the amount of payroll taxes the worker chooses to divert to personal accounts, instead of basing the amount on the size of the personal account annuity at retirement. ${ }^{38}$ Under Model 2, for instance, the amount foregone equals the worker's contributions plus a 2 percent real rate of return. Consequently, if the worker expected personal account investments to yield a real return higher than 2 percent, he or she would expect to be better off opting for the personal account. Because workers who opt for personal accounts expect to receive the full amount of each dollar of investment returns above the two percent threshold, the policy does not distort investment incentives. The policy also has the desirable feature that it minimizes any adverse impacts of personal accounts on Social Security's progressivity. High-wage workers will forego a larger share of their traditional benefits than will low-wage workers for each dollar of personal account contributions. ${ }^{39}$

\section{Administrative Considerations}

In developing models for Personal Retirement Accounts within a reformed Social Security system, Commissioners agreed that a reasonable structure would have to balance four primary objectives. First, administrative fees and charges would have to be reasonable, so investment assets would be anticipated to enhance retirement security. Second, competition among fund managers was felt to be quite important, as a means of helping protect workers and

\footnotetext{
37 Alternatively, as Koitz et al. (2001) noted, "the annuities or periodic payments these accounts would yield could go a long way to offsetting constraints on future Social Security benefits that may be considered to restore the system's solvency....people could be even better off than if future Social Security benefits were fully financed (i.e., fully payable)."

${ }^{38}$ The Commission avoided conditioning first-tier benefits on the actual amount that workers had in their personal accounts at retirement. All Commissioners were firmly opposed to any "clawback" aspect in a PRA design.

${ }^{39}$ The Commission also considered an alternative approach in which the percentage of Social Security benefits a worker would be required to forego would depend upon the percentage of payroll taxes the worker diverted to personal accounts. Under such an approach, a worker who diverted 20 percent of his payroll taxe s to personal accounts would forgo, say, 20 percent of his benefits. This approach was rejected for two reasons. First, it would create a greater incentive for high-wage workers to opt for personal accounts than low-wage workers. Second, it would not preserve as much of Social Security's progressivity as the Commission's recommended approach.
} 
retirees against the possibility of poor service in their PRA accounts. Thirdly, it was essential to ensure that plan participants' contributions could be deposited into the personal accounts in an orderly and timely manner, while not imposing excessive compliance costs on employers. These challenges were prominent in most of our discussions regarding administrative design and structure, since unless such a system operates quickly, fairly, and effectively, workers might be less likely to opt into the program.

Substantial study and discussion focused on the desirable design and structural aspects of a sensible PRA plan. In the end, the Commission proposed starting with a centralized approach, similar to the Federal Thrift Saving Plan that today covers civil servants and military employees. Under this format, a single central Governing Board would collect contributions, manage records, and, via a competitive process, select the private-sector managers who could invest participant assets. In addition, record keeping and benefit payments could be handled by the Governing Board. This, we felt, reflected "state of the art" input on likely costs and benefits of alternative plan designs, economic measures of scale economies, and a balancing of the benefits of centralization versus the attractiveness of enhanced competition. ${ }^{40}$ After a few years, plan participants who had accumulated some minimum amount of assets would be permitted to move their investments from the government-run plan into licensed, competitive, and privatelymanaged plans. Diversification in providers should avoid the centralized control that a PRA Governing Board might otherwise exercise. In all cases, of course, the accounts would be required to investing in the broad range of corporations across all major commercial sectors; further, the amount of the fund invested in any particular corporation could not significantly exceed the market value of the corporation relative to other corporations in the fund. This twophase approach offered the key advantage of avoiding the need to regulate levels of fund loads or charges, since competition and information provided by the central fund administrator would be anticipated to drive down fees and charges.

Investment Choices for PRAs

When analyzing the investment options offered under a PRA system, the Commission again drew on the experience of the US Government Thrift Saving Plan (TSP). Even prior to the collapse of Enron and other media-garnering recent corporate bankruptcies, members recognized

\footnotetext{
${ }^{40}$ For an extensive discussion of administrative design issues see Shoven (2000), Feldstein and Liebman (2002), and Shipman (1999).
} 
that participants must be provided with a range of well-diversified investment choices. Consequently the most sensible tack was to offer investors a choice of indexed portfolios including a Government Securities Investment (G) Fund; a Fixed Income Index Investment (F) Fund; a Common Stock Index Investment (C) Fund; a Small Capitalization Stock Index Investment (S) Fund; and an International Stock Index Investment (I) Fund. ${ }^{41}$ In addition, the Commission recommended that one investment option include Government Treasury InflationProtected Securities. As is currently the case with the TSP, and to ensure low management fees, the funds would be managed by private-sector investment managers selected via a competitive bidding process. ${ }^{42}$ Furthermore, recent economic research suggested that it would be necessary to offer participants a balanced portfolio should workers and retirees fail to indicate how to allocate their PRA investments. ${ }^{43}$

\section{Actuarial Assumptions}

Assessing Social Security reform plans requires projecting future costs and benefits under alternative scenarios, building on assumptions regarding anticipated future mortality rates, wage and productivity growth rates, returns on equities and bonds, and administrative costs. In keeping with past practice of having serious proposals vetted for consistency, the Commission reform plans were scored by the Office of the Chief Actuary at the Social Security Administration (OACT). This office provided the actuarial assumptions used in cost and benefit projections developed under advisement from the Social Security Board of Trustees. ${ }^{44}$

For the most part, the OACT assumptions are well-known and widely discussed, so we do not dwell in depth here on these. The OACT's projections assume an expected future real return on stocks of 6.5 percent. Corporate and Treasury bonds were assumed to deliver a real rate of return of 3.5 percent and 3.0 percent, respectively. The Actuary's projections further assumed

\footnotetext{
${ }^{41}$ As elaborated in the report, the G Fund holds mainly short-term U.S. Treasury securities issued solely to the TSP, while the F Fund seeks to track a U.S. bond market index. The C Fund tracks the Standard \& Poor's 500 Index of large-company stock while The S Fund tracks the Wilshire 4500 stock index. The I Fund holds corporate assets located in Australia, Europe and the Far East.

${ }^{42}$ Designing PRAs also requires specifying how frequently workers will be able to change their account allocations, and what these asset choices might be. After reviewing other countries' experiences, Commissioners recognized that allowing participants to freely change PRA fund investments would be costly, though it would enhance participants' sense of ownership over their accounts. Ultimately we proposed that PRA investors should be permitted to change investment allocations annually and access account information at any time (e.g. over the telephone or internet). This, we felt, met the need to encourage participants to think of their investments as "long-term savings" rather than short-term funds.

${ }^{43}$ See for instance Benartzi and Thaler, (2001); Choi et al. (2001); and Mitchell and Utkus (2002).
} 
that a typical participant holds a balanced fund, with half of the assets in a broadly diversified equity portfolio and half in a similarly diversified bond portfolio. PRA administrative costs are assumed to total 30 basis points ( 0.3 percent of the account balance). Commissioners regarded these assumptions as conservative, since a model based on the Federal Thrift Savings Plan would likely have much lower actual expenses. The U.S. Government's Thrift Savings Plan, for example, operates with administrative costs of only 8 basis points. Also, under the OACT's rate of return and portfolio composition assumptions, the expected real return net of expenses is 4.6 percent. This expected return is much lower than that used in many academic and policy studies of personal accounts, and it is also well below historical US equity real returns.

\section{Access to Funds}

In designing the PRA structure, Commissioners thought hard about whether to permit access to the funds prior to retirement. On the one hand, all agreed that retirement funds should be earmarked for old-age, implying that workers should not be permitted to consume the assets if it would leave them dependent on government anti-poverty programs during retirement. On the other hand, a clear appeal of PRAs is that they reduce political risk by granting workers ownership over their own assets. This latter view was of particular concern regarding workers anticipating below-average life expectancies, such as African-Americans, the ill, and the lifetime poor.

Ultimately, the Commission concurred that, as long as the worker remained alive, his or her personal account funds would have to be preserved until retirement. The Commission concluded that pre-retirement stringencies should not permit individuals to face even greater stringencies during retirement. This philosophy is in keeping with current Social Security policy, since benefits now cannot be accessed prior to retirement nor used as collateral for a loan. Even workers with short life expectancies benefit from the PRAs, of course, since survivors and former spouses would be better protected than under today's Social Security rules. Thus widows and widowers today are exposed to financial insecurity, so we stipulated that PRAs could be passed on to survivors. Additionally, PRA assets accumulated during marriage would have to be

\footnotetext{
${ }^{44}$ The Annual Report of the Board of Trustees of the Federal Old -Age and Survivors Insurance and Disability Insurance Trust Funds (www.ssa.gov) contains a full discussion of key economic and demographic assumptions.
} 
divided between divorcing partners, to enhance protection of former spouses as compared to today's Social Security rules that do not recognize marriages lasting under ten years. ${ }^{45}$

Commission members also felt strongly that PRA funds would have to permit retirees a range of withdrawal approaches. Today's Social Security system lacks choice, inasmuch as all benefits must be fully annuitized at retirement. Drawing on economic studies of annuity markets, our plan proposed that account distributions could take the form of an annuity or periodic withdrawals, much as the current $401(\mathrm{k})$ system. ${ }^{46}$ To reinforce the perspective that PRA funds belong to workers, the Commission made two additional recommendations. First, a portion of funds above a minimum threshold would be accessible as a lump-sum distribution. ${ }^{47}$ Second, remaining assets could be bequeathed to loved ones at death. Because lower income households, especially lower income minority household's have shorter life-expectancies, the bequest option adds to the Social Security system's progressivity.

One topic of debate on the Commission pertained to how participants might invest their

PRA assets after retirement, and whether they might switch to conservative investments at some given age. Since relatively little is known about this question, we proposed a range of choices in the Report. The main results assumed that a typical individual would hold his PRA funds in a 50/50 balanced stock and bond fund during both the accumulation and decumulation periods (with the assumed return mentioned above of 4.6 percent after inflation). Consequently if the underlying investment portfolio returned more than this amount, the variable annuity in retirement would have benefits rise, whereas if the portfolio returned less than expected, real benefit values could fall. For those preferring greater security, and because the current Social Security system pays benefits entirely as an inflation-indexed annuity, Commissioners also

\footnotetext{
${ }^{45}$ All the CSSS reform plans recognize the historical relationship between Disability Insurance (DI) benefits and Old-Age and Survivors (OASI) defined benefits. Today, the Primary Insurance Amount benefit formula is a common one, and the programs' finances are affected in similar ways by demographic changes. Hence DI program outlays are projected to rise by 45 percent as a percent of payroll over the next 15 years, and DI costs will exceed DI tax revenue starting in 2009. The Commission acknowledged that a reformed Social Security system must take into account the fact that planned retirement is a very different life event from an unplanned onset of disability. Personal retirement accounts are intended to partially replace the defined benefit component in Social Security. DI beneficiaries with abbreviated work histories might have relatively low account balances. Some may argue that this justifies isolating the DI defined benefit structure from any changes that would affect OASI defined benefits, but testimony provided to the Commission indicated that many DI beneficiaries sought to maintain a parallel structure for both DI and OASI. We recommended further analysis to determine the optimal approach to balancing these adequacy and equity concerns in the DI system.

${ }^{46}$ See Brown et al (2001) on developments in annuity markets.
} 
proposed permitting inflation-indexed annuities during the retirement phase. In this context, it is worth noting that only about one-quarter of total Social Security income would be held in stocks, including both traditional system plus PRA benefits. Further as Brown et al. (2000) showed, retirees already receiving a real annuity under the traditional OASI system would prefer variable rather than more real annuities, under plausible assumptions about risk-aversion. ${ }^{48}$

\section{Benefits Under the Reformed System}

In discussions among fiscal sub-group members about how to display projected benefit levels, the issue arose as to whether we should adjust personal account annuities for financial risk. Commissioners felt that recognizing the existence of financial risk is important and that risk-adjustment is an appropriate way to account for it. As we noted earlier, both personal accounts and traditional Social Security benefits are subject to risk. Therefore, to adjust personal accounts for risk while not similarly adjusting traditional Social Security benefits for their political, economic, and demographic risks would produce benefit comparisons misleading to policymakers and the public. After some discussion, fiscal sub-group members agreed that the best approach would be to present all annuities in terms of their respective expected values and to discuss the risks of each annuity in a qualitative manner.

It is useful to summarize the overall reform plans by commenting on projected retiree benefits under the CSSS reforms. All workers who opt for personal accounts under Model 2, for instance, can anticipate retirement benefits at least as high as today's benefits, adjusted for inflation; most would also anticipate payments higher than those the system can afford to pay in the future under current law. Results are summarized in Figure 2, which displays anticipated benefits for low, medium, and high-earner workers who elect personal accounts. (All benefit levels are expressed in \$2001).

Inasmuch as the system is progressive, the pattern of benefits received will vary by earnings levels. Here we focus on the worker who elected a "medium yield" investment

\footnotetext{
${ }^{47}$ The threshold amount is designed so that the yearly income received from an individual's Social Security benefit plus the joint annuity (if married) prevents either spouse from falling below the poverty line during retirement, taking into account expected lifetimes and inflation.

${ }^{48}$ Another controversial question had to do with the financial and economic costs and benefits of providing guaranteed investments in the context of the PRA structure. The Commission elected not to propose PRA guarantees, instead calling for more research on the likely structure of such investment options. For relevant research on pension guarantees see Bodie (2001); Bodie and Merton (1993); Feldstein and Ranguelova (2000); Lachance and Mitchell (2002), and Smetters (2002), among others..
} 
portfolio; results for other patterns are indicated in the Figure. ${ }^{49}$ Under this reform plan, a new labor market entrant planning on retiring in 2052 could expect benefits $42 \%$ larger than today's benefits, assuming he earned average earnings over his career. Results are even better for low earners, where the increment would be an even larger $65 \%$ in real terms, compared to today's retiree. High-wage workers would also anticipate a benefit increase, but the percentage increment is lower, at $40 \%$, in keeping with the progressive intent of the reform. We also note that benefits anticipated under all three investment scenarios are at least as high as benefits payable given expected system revenues, so that even conservative investors could expect to do at least as well as under current law, if not better.

Figure 2 here

The figure shows that, in all cases, expected benefits will be higher than what today's retirees receive, and higher than what can be paid under the current system. Also, in each future retiree cohort, low-wage workers will expect the largest benefit increases and high-wage workers will anticipate the smallest increases. The enhanced progressivity results from the fact that PRAs are initially capped at $\$ 1,000$, so low-wage workers earning $\$ 25,000$ or less can redirect 4 percentage points of the payroll taxes, but workers earning above $\$ 25,000$ can redirect only a smaller percentage. Additionally, as was noted above, improved protections are provided against poverty, so benefit levels paid to all low-wage workers are raised.

\section{Impact on Federal Government Finances}

The Commission's fiscal sub-group devoted considerable time to the issue of measuring the impact of proposed reforms on the federal government's finances. For several reasons, measuring the impact is not as straightforward as it might first appear. One is that the federal budget does not currently recognize the existence of long-term Social Security debt, and failure to recognize this debt can create the false appearance among policymakers that there is little financial benefit from moving from a PAYGO system to a funded system that reduces long-term Social Security liabilities. Though most economists would not make such a mistake, shortsighted critics have done so. Additionally, the sheer complexity of the federal government's financial accounting system makes it difficult to communicate the impact of reform to the public.

\footnotetext{
${ }^{49}$ Recall that the inflation-adjusted mediu m return is 4.6 percent. The OACT also computed results assuming a lower yield of 2.7 percent and a higher yield of 4.92 percent. (see Commission Final Report, pages 18-19).
} 
A related problem is that traditional tools for measuring the impact of reform, such as the longterm actuarial balance, are ill-suited to capturing the full-financial impact of moving to a funded system.

In consideration of the foregoing, perhaps the best place to start is with a qualitative look at the impact of particular reforms on Social Security finances. Figure 3 indicates the impact of Model 2 on Social Security's financial shortfall, its net surpluses and deficits, over the next 75 years. ${ }^{50}$ As the chart shows, under current law, Social Security is expected to run cash surpluses until 2016. ${ }^{51}$ After 2016, annual deficits become a permanent fixture. Annual deficits as a percentage of taxable wages are expected to rise to nearly 2 percent by 2020,4 percent by 2030 , and to over 6 percent by 2075, the last year of Social Security's actuarial horizon. Under Model 2, annual deficits begin a few years sooner, in 2010. They rise more slowly and peak at 4 percent of payroll in 2030, the same level of current law deficits that year. Surpluses are first achieved in 2059 and continue to rise thereafter. Consequently, the reform proposal ultimately replaces current law's permanent and rising deficits with rising surpluses. By the end of the 75year actuarial horizon, the surpluses are expected to reach $1.4 \%$ of payroll. The projected surpluses from 2059 forward, although in the distant future, would give future Congresses the flexibility to increase traditional Social Security benefits should it deem any increases desirable. Figure 3 here

Naturally the interesting question for policymakers is how one can quantify the reform proposal's improvement in Social Security's finances. One useful summary statistic is the reduction in the amount of additional government revenues required to finance promised benefit payments. Yet even this seemingly straightforward statistic is subject to measurement problems. As noted above (Section II), the Social Security actuaries use a fixed 75-year time horizon which truncates the returns to the government that accrue in the form of lower traditional Social Security liabilities for persons who opt for personal accounts. These lower Social Security liabilities translate into lower governmental revenue requirements dollar-for-dollar. The magnitude of the excluded lower revenue requirements is not trivial: according to calculations

\footnotetext{
${ }^{50}$ All estimates assume 2/3 participation rates in the PRAs, consistent with the Co mmission's view that this would represent likely participation rates. Alternative participation results appear in the Report.

${ }^{51}$ Cash surpluses and deficits are measured using expenditures for benefits and administration, and revenues from payroll taxes and income taxes of Social Security benefits. Receipts from any remaining intergovernmental transactions are excluded. Hence, the surpluses and deficits measure cash transactions between the federal government and the public.
} 
performed for the Commission by the Social Security actuary, the present value of the reduced revenue requirements under Model 2 that are excluded because of the fixed time horizon total about $\$ 1$ trillion dollars.

One solution to this problem is to calculate the change in revenue requirements in perpetuity. However, since the mid-1960s, the Social Security actuaries have ceased making the economic and demographic assumptions beyond the 75-year horizon.

Keeping in mind this measurement problem, Table 1 presents three alternative measures of the reduction in governmental revenue requirements required to finance benefit payments under Model 2 compared to current law. All three measures are expressed in present value terms.

\section{Table 1 here}

The first row compares the change in the governmental revenue requirement to the traditional measure of Social Security's current law requirement. This traditional measure is the present value of the difference between Social Security's outgo and its income over the 75-year actuarial horizon, less the balance in the fund at the beginning of the time period. The inclusion of the beginning balance implicitly assumes that past Social Security surpluses have been "saved", i.e., they have been used to reduce the national debt, and hence, are available to finance future deficits. The inclusion of future surpluses in the traditional measure implicitly assumes that future surpluses will be similarly used and hence will be similarly available to finance future deficits. The Trustees estimate the magnitude of this traditional measure of the program's general revenue requirement at $\$ 3.2$ trillion. $^{52}$

Assuming that future Social Security surpluses are available to finance future deficits, the appropriate measure to use to calculate the reduction in the government's revenue requirements is the net change. This measure includes both the reduction in Social Security surpluses during years in which Social Security runs surpluses, and the change in deficits during years in which Social Security incurs deficits. The Social Security actuaries compute the present value of this amount as \$2.0 trillion. Compared to the traditional measure of the government's revenue requirement under current law, this represents a 63 percent reduction.

An alternative (row 2, Table 1) is to recognize that Congress has previously used Social Security surpluses to finance consumption-related spending increases and tax reductions rather

\footnotetext{
${ }^{52}$ The measure, when expressed as a percentage of taxable payroll over the same time horizon, is called the actuarial balance. In 2001, the actuarial balance is -1.86 percent.
} 
than for debt reduction, but it then assumes that future Congresses (including next year's) will use Social Security surpluses for debt reduction. Under this alternative, the beginning balance, which totals $\$ 900$ million, is not available for finance future deficits either under current law or under the proposed reform. The current law general revenue requirement is $\$ 4.1$ trillion, and the $\$ 2$ trillion future net deficit reduction is a 49 percent reduction.

A third alternative (row 3) recognizes that future Congresses, like their predecessors, will not "save" Social Security surpluses. Under this alternative, future (as well as past) surpluses are not available to finance future deficits. The current law government revenue requirement is the present value of the deficits in deficit years: $\$ 5.1$ trillion. The amount by which the reform proposal reduces the government revenue requirement rises to $\$ 2.3$ trillion, a 45 percent reduction from current law. The $\$ 300$ billion increase represents the amount of surplus Social Security payroll taxes that are devoted to personal accounts rather than to consumption-related tax increases or tax reductions.

While these data do a decent job on tallying the cost of implementing reforms versus adopting massive tax increases, they do not highlight the investment required when moving to a funded account system. Model 2, for instance, involves a temporary transfer of general revenues to ensure that solvency is achieved and benefits can be paid as specified.

\section{Transition Costs}

Inevitably there is an investment required when moving to a funded system, and this additional cost can be described with the aid of Figure 3. The graph shows that the investment period lasts from 2005 to 2029, and is balanced by a payback period from 2029 to the end of the valuation horizon. In this context, transition costs can be viewed as the net additional general revenue requirement associated with the proposed reform. In those years, additional resources are needed to insure that promised benefits can be paid and personal accounts can be funded. As shown in the chart, transition financing requirements would initially be comparatively small, $\$ 4$ billion in 2010, and would grow to a maximum of just over \$73 billion in 2016 (in \$2001). Thereafter, the amount of new cash requirements for the reformed system would diminish. Starting in 2029, the new system would require less general revenue than the old one on a permanent basis. In present value terms, Model 2 requires $\$ 0.9$ trillion or about half of one percent of GDP, between now and 2029. The Commission concluded that this amount was comparatively small and would not pose major economic or budget concerns. 


\section{Conclusion}

It is clear to us that social security reform is both economically necessary and socially imperative. If nothing is done to reform the system, low earners will be particularly vulnerable to benefit cuts, and all workers as well as retirees will confront substantial economic insecurity in old age. We anticipate that many workers would elect personal accounts if offered the choice, particularly when they understand the substantial political risk they face under the current Social Security system, where promised benefits cannot be paid under available revenues.

The 2001 Commission to Strengthen Social Security did its work against a backdrop of looming fiscal insolvency in the largest single program operated by the US federal government. Our report, informed by a rich range of economic policy research carried out over the last four decades, developed reform scenarios that incorporate personal retirement accounts as a central element in a modernized system of old-age security in America. The Commission's proposed two-tier system offers an enhanced and more reliable safety net, while also providing workers the opportunity to invest in personal accounts with diversified investment choice and potentially lower political risk. These reforms would also put Social Security on a self-financing basis for the first time in over a quarter of a century, consistent with what was envisioned by its founder, Franklin Delano Roosevelt. 


\section{Bibliography}

Aaron, Henry, and Barry Bosworth, and Gary Burtless, Can America Afford to Grow Old, Brookings Institution, Washington, D.C., 1988

Aaron Henry J., and John B. Shoven, Should the United States Privatize Social Security? The Alvin Hansen Symposium on Public Policy, Harvard University, MIT Press, Cambridge, MA, London, England, 1999.

Advisory Council on Social Security, Report of the 1994-96 Advisory Council on Social Security, Vo 1. I: Findings and Recommendations, 1997.

Advisory Council on Social Security, Report of the 1979 Advisory Council on Social Security, Committee on Ways and Means, House of Representatives, $96^{\text {th }}$ Congress, $1^{\text {st }}$ Session, December 7, 1979.

Auerbach, Alan, Jagadeesh Gokhale and Lawrence Kotlikoff, "Generational Accounts: A Meaningful Alternative to Deficit Accounting, in D. Bradford (ed) Tax Policy and the Economy, Vol.5 MIT Press, Cambridge, 1991.

Benartzi, Shlomo and Richard Thaler. 2001. "Naïve Diversification Strategies in Retirement Savings Plans," American Economic Review. 91(1), pp. 79-98.

Blahous, Charles P., Reforming Social Security, Praeger, Westport, Connecticut, London, 2000.

Board of Trustees, The 2001 Annual Report of the Board of Trustees of the Federal Old-Age and Survivors Insurance and Disability Insurance Trust Funds, U.S. Government Printing Office, March 2001.

Bodie, Z. "Financial Engineering and Social Security Reform." In Risk Aspects of Social Security Reform. Eds. J. Campbell and M. Feldstein., Univ. of Chicago Press, 2001.

Bodie, Z. and R. Merton. "Pension Benefit Guarantees in the United States: A Functional Analysis." In The Future of Pensions in the United States. Ed. R. Schmitt. University of Pennsylvania Press, 1993.

Boskin, Michael J. "Alternative Social Security Reform Proposals," Paper presented to the National Commission of Social Security Reform, August 20, 1982

Brown, Jeffrey R., Olivia S. Mitchell, James M. Poterba. "The Role of Real Annuities and Indexed Bonds in an Individual Accounts Retirement Program.” Risk Aspects of Investment-Based Social Security Reform. Eds. John Y. Campbell and Martin Feldstein. 2000: 321-360.

Brown, Jeffrey, Olivia S. Mitchell, James Poterba, and Mark Warshawsky. The Role of Annuity Markets in Financing Retirement. MIT Press, 2001.

Choi, James, David Laibson, Brigitte Madrian, and Andrew Metrick, "Defined Contribution Pensions: Plan Rules, Participant Decisions and the Path of Least Resistance," In NBER Tax Policy and the Economy, forthcoming.

Cogan, John, “The Congressional Response to Social Security Surpluses, 1935-94”, Essays in Public Policy, The Hoover Institution, Stanford CA, 1998.

Commission on the Social Security "Notch" Issue, Final Report on the Social Security "Notch" Issue, Washington, D.C., December 31, 1994.

Commission to Strengthen Social Security (CSSS), Interim Report, Washington, D.C., August 2001.

Commission to Strengthen Social Security (CSSS), Strengthening Social Security and Creating Personal Wealth for all Americans, Final Report, Washington, D.C., December 2001.

Committee on Ways and Means, U.S. House of Representatives, 2000 Green Book, U.S. Government Printing Office, October, 2000.

Congressional Budget Office. "Social Security And Private Saving: A Review Of The Empirical Evidence,” July 1998.

Consultant Panel on Social Security, Report of the Consultant Panel on Social Security, Joint Committee Report, $94^{\text {th }}$ Congress, $2^{\text {nd }}$ Session, August 1976. 
Coronado, Julia Lynn, Don Fullerton, Thomas Glass, "The Progressivity of Social Security”, NBER, February, 2000.

Crain, Mark W. and Michael L. Marlow, "The Causal Relationship Between Social Security and the Federal Budget, in Social Security's Looming Surpluses: Prospects and Implications, Weaver (ed), AEI Press, Washington D.C., 1990

Derthick, Martha, Policymaking for Social Security, The Brookings Institution, Washington D.C., 1977.

Feldstein, Martin, “The Missing Piece in Policy Analysis: Social Security Reform”, American Economic Review, 86, May 1996.

Feldstein, Martin and Jeffrey B. Liebman. "Social Security”. NBER Working Paper 8451, September 2001.

Feldstein, M. and E. Ranguelova. "Accumulated Pension Collars: A Market Approach to Reducing the Risk of Investment-Based Social Security Reform.” NBER Working Paper 7861, August 2000.

Feldstein, Martin and Andrew Samwick. "Potential Paths of Social Security Reform". NBER Working Paper 8592, November 2001.

Feldstein, Martin S. and Jeffrey Liebman. The Distributional Aspects of Social Security and Social Security Reform. University of Chicago. 2002.

Gramlich, Edward M. "Different Approaches for Dealing with Social Security." The Journal of Economic Perspectives 10(3) Summer, 1996): 55-66.

Gustman, Alan L. and Thomas L. Steinmeier, "How Effective is Redistribution Under the Social Security Benefit Formula", NBER Working Paper, March 2000.

Hsiao, William, "An Optimal Indexing Method for Social Security”, in Financing Social Security, Colin D. Campbell (ed), American Enterprise Institute, Washington, D.C., 1979.

Koitz, David, Seeking Middle Ground on Social Security Reform, Hoover Institution Press, Stanford CA, 2001.

Koitz, David; Geoffrey Kollmann and Dawn Nuschler. 2001. "Social Security: What Happens to Future Benefit Levels Under Various Reform Options”, Congressional Research Service, Domestic Social Policy Division, August 20. US GPO.

Lachance, Marie-Eve and Olivia S. Mitchell. "Understanding Individual Retirement Guarantees." Pension Research Council Working Paper, Wharton School. 2002.

Leibman, Jeffrey, "Redistribution in the Current U.S. Social Security Program", Harvard University Working Paper, July 2001.

Mitchell, Olivia S. and Steve Utkus. "Company Stock and Retirement Plan Diversification." Wharton School, Pension Research Council Working Paper, 2002.

Moynihan, Daniel Patrick, "Social Security Saved!" Address to the Institute of Politics: Spring Exercise on Social Security Reform, John F. Kennedy School of Government, Harvard University, March 16, 1998.

President's Commission to Strengthen Social Security, Strengthening Social Security and Creating Personal Wealth for All Americans, December, 2001.

Schieber, Sylvester J., and John B. Shoven, The Real Deal: The History and Future of Social Security, Yale University Press, New Haven and London, 1999.

Schwarz, Anita. "International Experience with Private Retirement Accounts," Testimony before the President's Commission to Strengthen Social Security, September 6, 2001

Shipman, William. "Administrative Challenges Confronting Social Security Reform," Testimony before the House Budget Committee Task Force on Social Security, April 27, 1999.

Smetters, Kent, "Controlling the Cost of Minimum Benefit Guarantees in Public Pension Conversions", $\underline{\text { Journal of }}$ Pension Economics and Finance, March 2002. 
Smetters, Kent, "Has Mental Accounting Been Successful in Saving Social Security Surpluses?" The Wharton School,Working Paper, University of Pennsylvania, 2002

Shoven, John, ed. Administrative Aspects of Investment-Based Social Security Reform University of Chicago. 2000.

Shoven, John B., "Implementing a Two-Tier Social Security Program”, Testimony to the President's Commission to Strengthen Social Security, September, $6^{\text {th }}, 2001$.

Weaver, Carolyn L., "The Crisis in Social Security”, Duke Press Policy Studies Working Paper, Durham North Carolina, 1982.

Weaver, Carolyn L. (ed), Social Security's Looming Surpluses: Prospects and Implications, AEI Press, Washington D.C., 1990.

World Bank Pensions Primers. http://wbln0018.worldbank.org/HDNet/HDdocs.nsf/view+to+link+webpages/1ff73e261420a8f4852568ac0 06bb4e9?OpenDocument. Various dates. 
Figure 1: Promised Increases to Future Retirees, As Compared to Current Retirees: Current Law Monthly and Lifetime Benefits

Source: CSSS Final Report (2001)

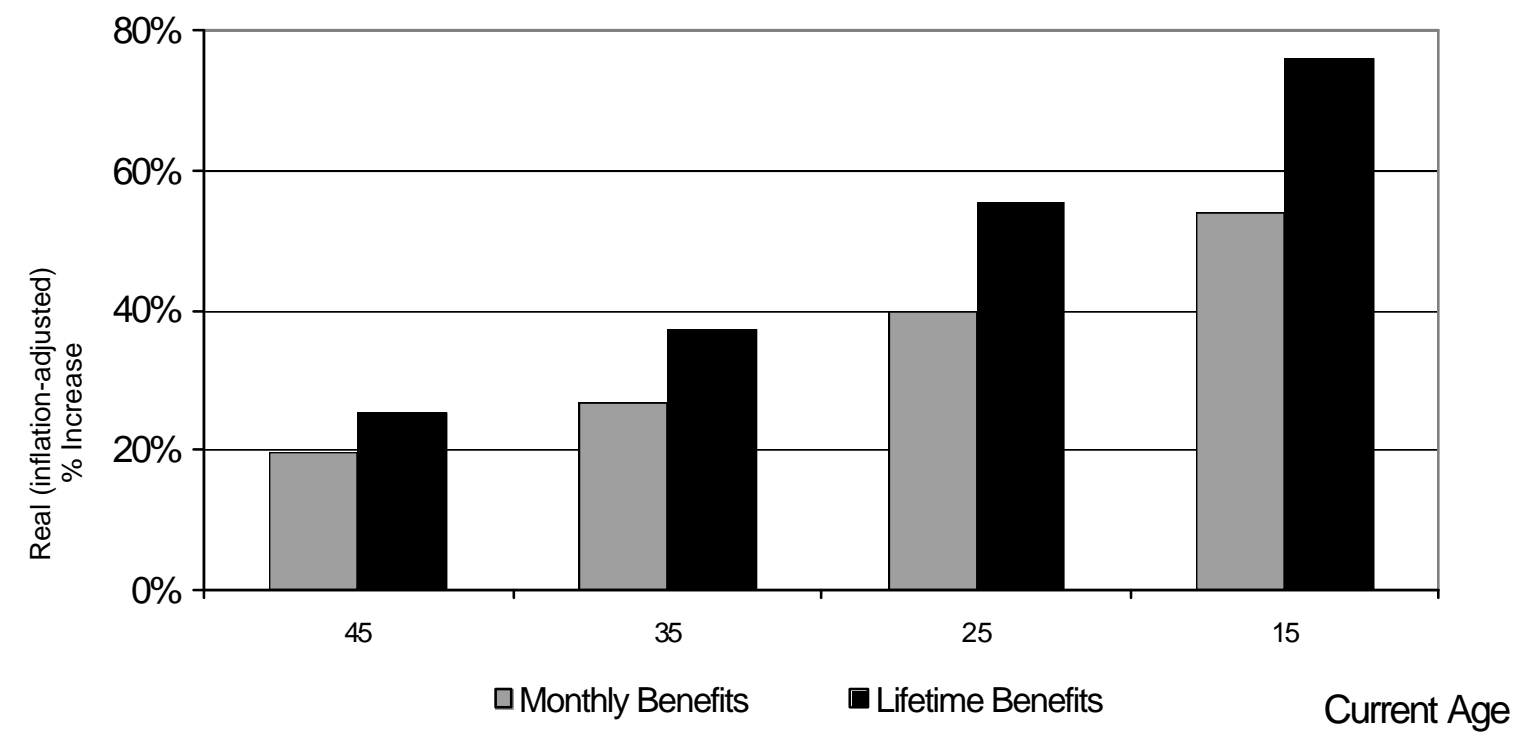


Figure 2: Monthly Social Security Benefits Under Alternative Scenarios (2052, Model 2)

Source: CSSS Final Report (2001)

\section{A. Lifetime low-wage earner}

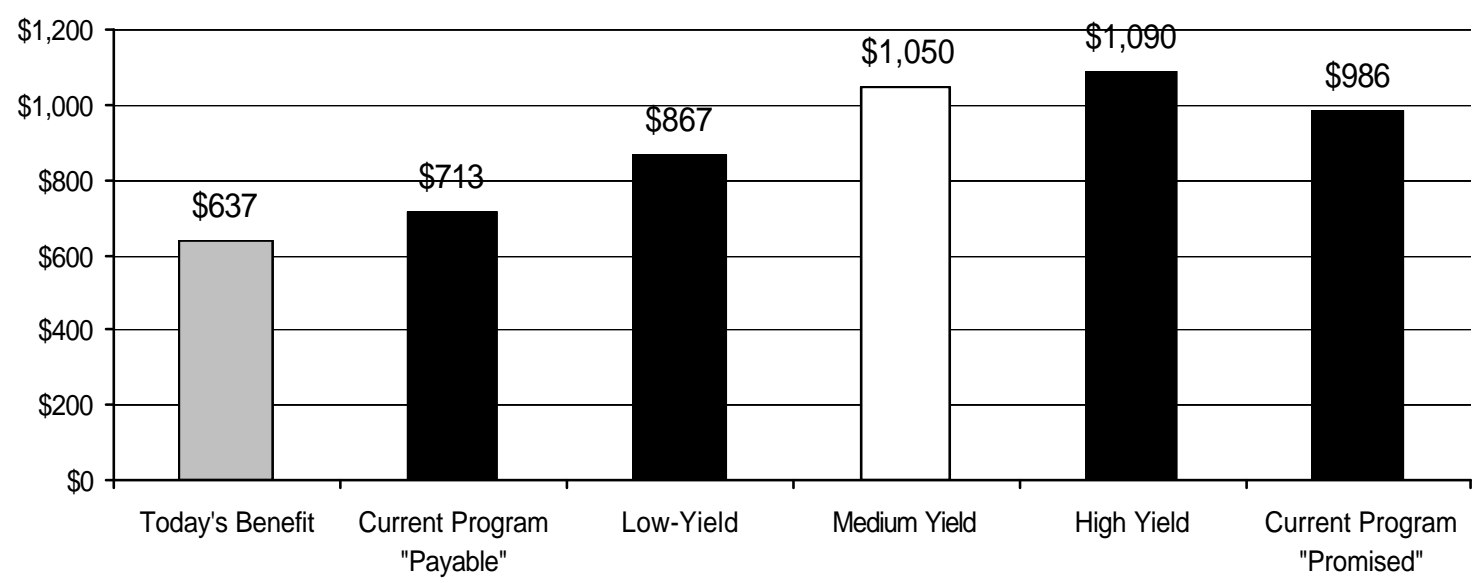

\section{B. Lifetime medium-wage earner}

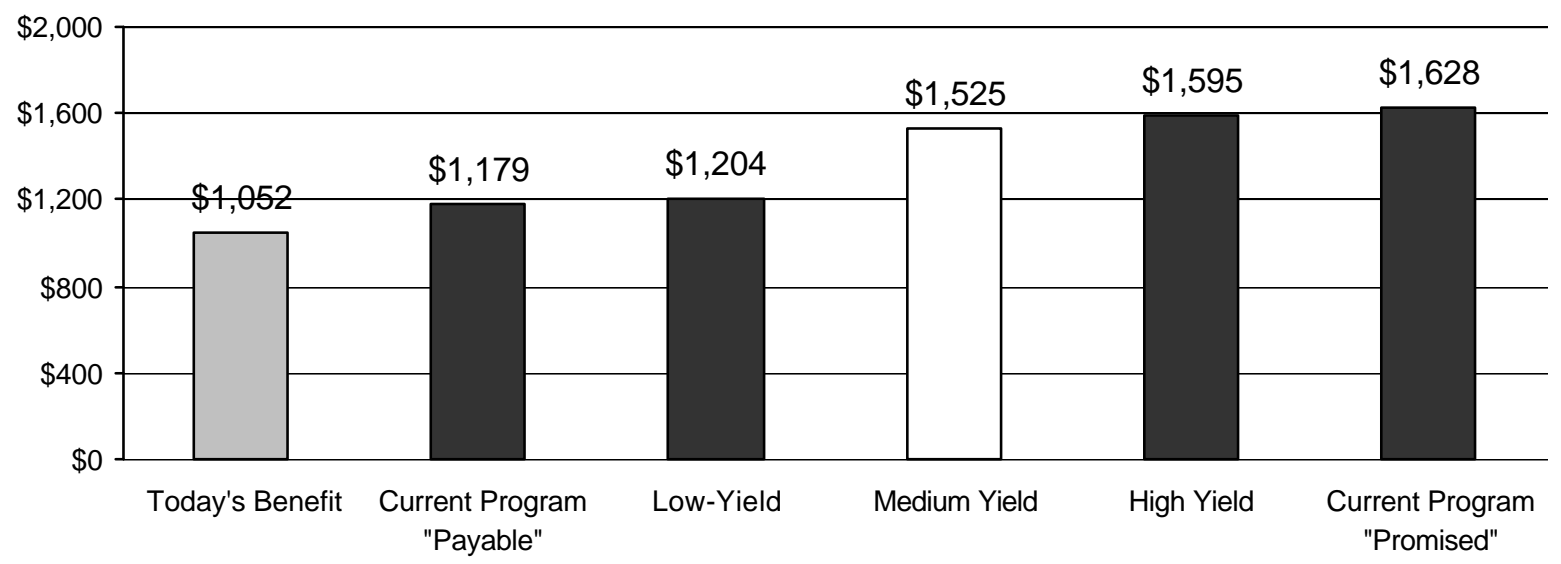

\section{Lifetime high-wage earner}

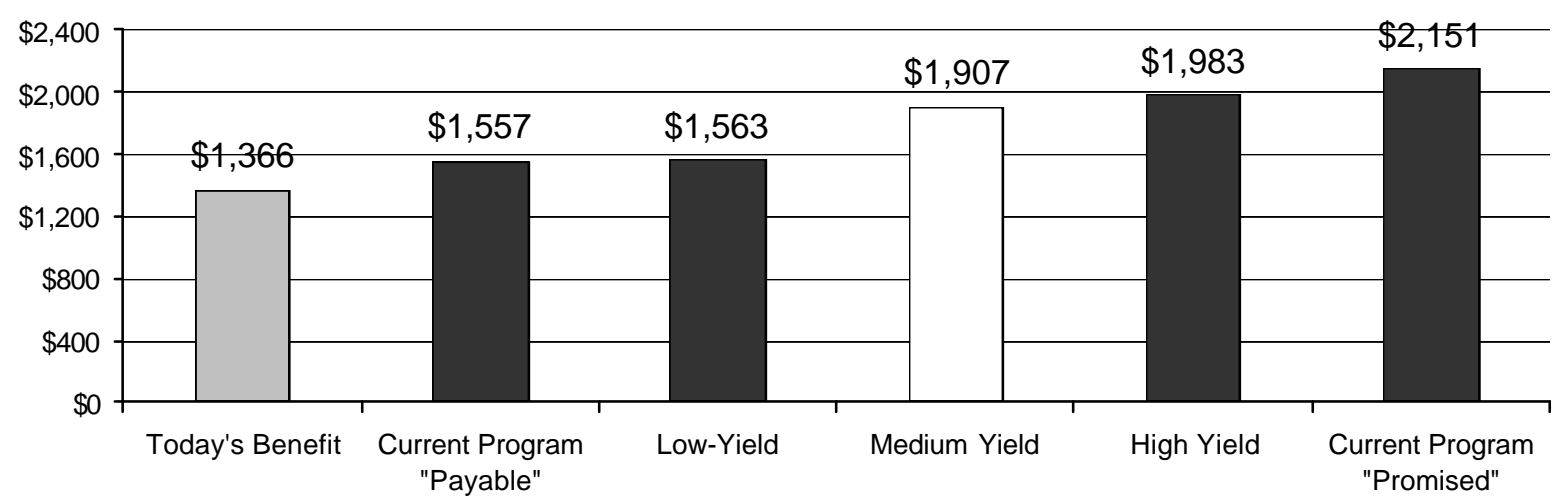


Figure 3. Impact of Commission Proposed Reform on Social Security Cash Flows (Model 2) Source: CSSS Final Report (2001)

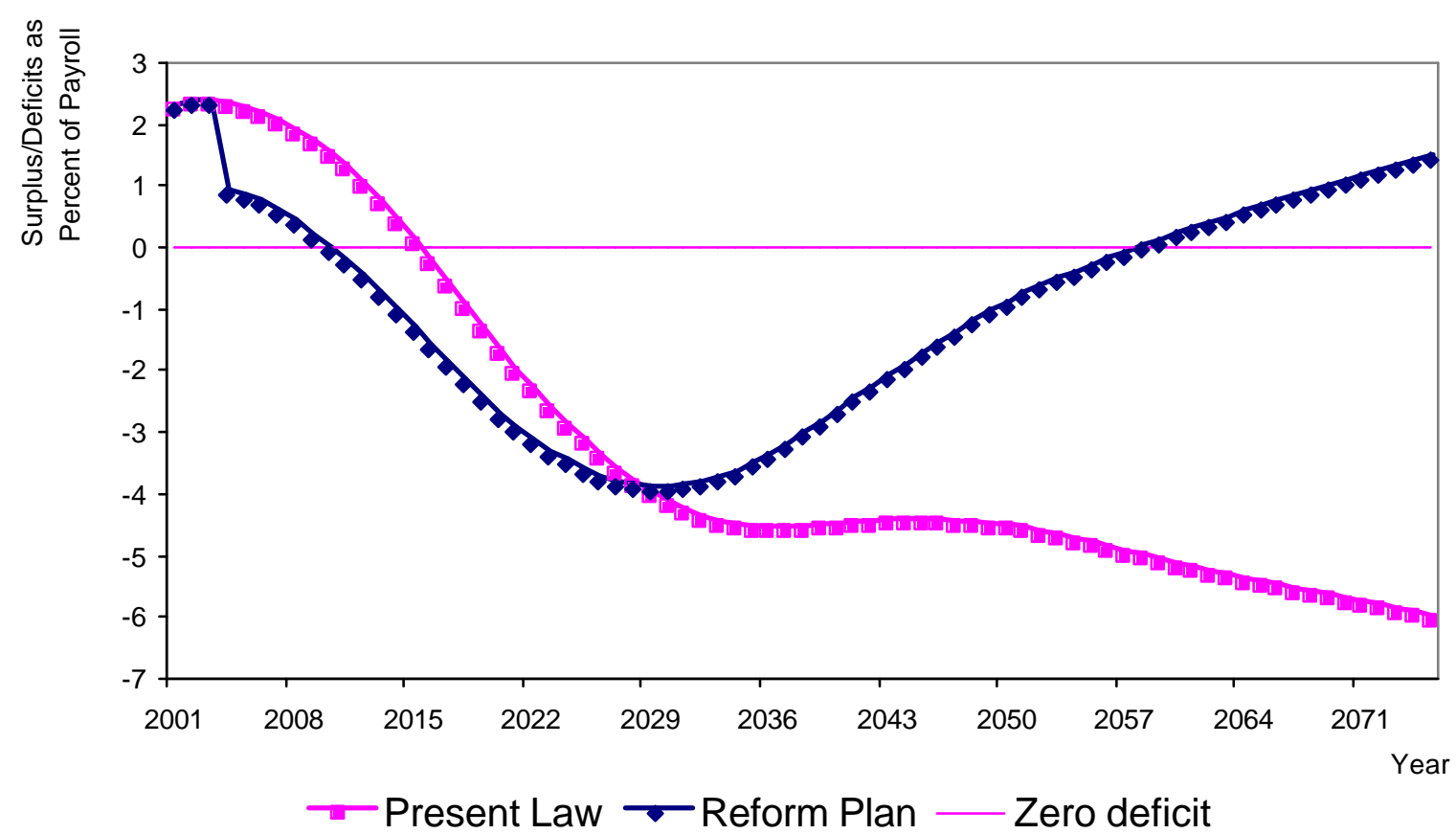




\section{Table 1: Impact of Social Security Reform on Government's Revenue Requirement}

Source: Authors computations, CSSS Report (2001)

\begin{tabular}{|c|c|c|}
\hline Current Law & \multicolumn{2}{|c|}{ Commission Reform Model 2} \\
\hline Revenue & Change in Revenue & cent \\
\hline $\begin{array}{c}\text { Requirement } \\
\text { (in PV trillions) }\end{array}$ & $\begin{array}{c}\text { Requirement } \\
\text { (in PV trillions) }\end{array}$ & duction \\
\hline
\end{tabular}

Traditional Measure

$\$ 3.2$

$-\$ 2.0$

$63 \%$

(Congress "saves" all surpluses)

$\$ 4.1 \quad-\$ 2.0 \quad 49 \%$

Alternative 2

$\$ 4.1$

(Congress spent surpluses,

but "saves" future surpluses)

Alternative 3

$\$ 5.1$

$-\$ 2.3$

$45 \%$

(Congress "spends" all surpluses) 